\title{
Inheritance and Reconstruction of the Chinese Wushu Spirit in Guangdong-Hong Kong-Macao Greater Bay Area
}

\author{
Jicheng Zhou \\ Zhuhai College of Jilin University \\ Zhuhai, China
}

\begin{abstract}
The spirit of Chinese Wushu in the GuangdongHong Kong-Macao Greater Bay Area is an important part of the Chinese Wushu family, and it is the crystallization of wisdom accumulated by the working people of South of the Five Ridges in long-term social practice. This article explores the development of Chinese Wushu in the Guangdong-Hong Kong-Macao Greater Bay Area, explains the modern value of Chinese Wushu spirit, and proposes countermeasures for its inheritance and remodeling.
\end{abstract}

Keywords-Guangdong-Hong Kong-Macao Greater Bay Area; Chinese Wushu; inheritance

\section{INTRODUCTION}

Chinese Wushu has a long history, extensive and profound. It carries the essence of thousands of years of Chinese traditional culture. It contains a profound Chinese national spirit and is a valuable asset of the Chinese nation. Chinese Wushu has long played an important role in people's lives and in the spiritual world. During the period of farming and civil society, Chinese Wushu began to appear. At this time, Chinese Wushu was closely linked with people's social production practices. In the era of cold weapons, Chinese Wushu is closely related to the military war and promotes mutual development. In modern times, due to the country's aggression and the need to "save the country", Chinese Wushu has become a means for people to defend their homeland. After entering the modern society, Chinese Wushu is more of a form of fitness and entertainment. It can be seen that the different responsibilities and value functions of Chinese Wushu will change in different historical periods.

Chinese Wushu not only has an external traditional fitness method, but also inherently contains and cultivates the national spirit. It is an excellent traditional culture of the Chinese nation. Chinese Wushu absorbed the essence of Chinese traditional culture in the development process, and thus formed a complete and independent Chinese Wushu spiritual system. Throughout the development of Chinese Wushu, the Chinese Wushu spirit includes sports,

*Fund: Innovative and innovative university projects in Guangdong Province in 2018 (Guangdong Province major and key scientific research projects featured innovative projects). "Research on the inheritance and talent cultivation of Chinese Wushu in Guangdong-Hong Kong-Macao Greater Bay Area based on health industry”. (Project No.: 2018GXJK248). entertainment, military and other functions, and has been guiding the development of Chinese Wushu's practice. The spirit of Chinese Wushu is also continually drawing on the wisdom and strength of the excellent traditional culture of the Chinese nation, forming a unique Chinese Wushu spiritual system that transcends external expressions. In the Guangdong-Hong Kong-Macao Greater Bay Area, there are many ethnic traditional sports with southern Guangdong characteristics. However, with the rapid development of science and technology, people's lifestyle has undergone great changes, and national traditional sports have been greatly affected. Many projects have gradually become marginalized, and traditional national sports as an immaterial inheritance form need to be rescued and protected. With the State Council promulgating "Several Opinions on Accelerating the Development of Sports Industry to Promote Sports Consumption", "Health China 2030" Planning Outline, "Guangdong-Hong Kong-Macao Greater Bay Area Development Planning Outline" and other documents, China's mass sports have been fast development of. With the advantages of geography and history, in the aspects of promoting the Chinese Wushu culture, inheriting and reshaping the spirit of Chinese Wushu, and promoting the international communication of Chinese Wushu, Guangdong-Hong Kong-Macao Greater Bay Area will usher in new development opportunities and play a greater historical and practical role.

\section{EXPLORATION AND DEVELOPMENT OF CHINESE Wushu In GuANGdong-Hong Kong-MaCAO GreATER BAY AREA}

The construction of Guangdong-Hong Kong-Macao Greater Bay Area discharged " $9+2$ " formation, and gathered nine cities including Guangzhou, Foshan, Zhaoqing, Shenzhen, Dongguan, Huizhou, Zhuhai, Zhongshan and Jiangmen, as well as Hong Kong and Macao. This is intended to promote the chemical reaction of the development of the Guangdong-Hong Kong-Macao Greater Bay Area, showing the advantages of each city, the mutual sharing of urban agglomerations, and collaborative innovation. It is both advanced and inclusive. The Guangdong-Hong Kong-Macao Greater Bay Area is located in the Pearl River Delta, the heart of the south of the Five 
carries the good quality of the Chinese people, but also shows the charm of Chinese traditional culture to the world, so that people all over the world can know Chinese culture through Chinese Wushu, which thus promotes the promotion and development of Chinese Wushu. At the same time, in the collision of international culture, Chinese Wushu, as an important carrier of Chinese traditional culture, not only carries forward the national culture and spirit of our country, but also strengthens the exchange of Chinese and Western culture.

\section{B. Meeting the Needs of Contemporary Leisure and Fitness}

With the development of information technology, Internet technology has penetrated into thousands of households, providing convenience and spiritual enjoyment for contemporary people's life, study and work. However, from another perspective, the convenience of technology and technology has given birth to the bad habits and behaviors of contemporary people. These living habits and behaviors bring certain crises to people's health. Chinese Wushu pays more attention to the overall development of individual physical literacy, and pays more attention to the development of individual's physical and mental potential. Effectively inheriting traditional Chinese martial arts and spreading it to thousands of households, making Chinese Wushu a lifestyle of people's leisure and fitness, can meet the needs of contemporary people to prevent diseases and strengthen the body, and thus promote the health of people in China.

\section{The Need for the Development of Harmonious Society}

"Health China 2030" Planning Outline points out that a harmonious society advocates a people-oriented society and pursues the harmonious development of people and society, between people and nature, and between people. Man is the main body of a harmonious society. Only when people develop healthily can they promote social progress and achieve a harmonious society. And Chinese Wushu has a promoting significance for purifying the individual mind and honing the body. At the same time, the concept of "human beings and feeling the world with Chinese Wushu" promoted by Chinese Wushu is exactly the same as the concept of harmonious society development. Therefore, the inheritance of Chinese Wushu is the need to construct the development of a harmonious society in China, promoting the all-round development of the national economy.

\section{MODERN VALUE OF THE CHINESE WUSHU SPIRIT IN GuANGDONG-Hong Kong-MaCAO GREATER BAY AREA}

\section{A. The Need to Promote National Culture}

Today, with the rapid development of society, international trade is becoming more and more frequent, and all countries are pushing their own culture to the international. This not only enhances the visibility of the country, but also makes the national culture recognized by other countries, which helps to enhance the influence and competitiveness of the country in the international arena. China is in the period of great national rejuvenation. Chinese Wushu, as one of the representatives of Chinese culture, will not decline to shoulder a responsibility of becoming a banner for China to go international. Chinese Wushu not only

\section{COUNTERMEASURE ABOUT THE INHERITANCE AND REINVENTION OF THE CHINESE WUSHU SPIRIT IN GuANGDONG-HONG Kong-MaCAO GREATER BAY AREA}

\section{A. Strengthening the Study of Chinese Wushu Theory}

In view of the difficulties of the current Chinese Wushu inheritance, it is necessary to further strengthen the study of Chinese Wushu theory in Guangdong-Hong Kong-Macao Greater Bay Area, and innovate in the original traditional martial arts form and content. At present, there is still a lack of understanding of the characteristics, nature and laws of Chinese Wushu in the Guangdong-Hong Kong-Macao Greater Bay Area. Although many Chinese Wushu workers 
and enthusiasts have made corresponding research on the rules and techniques of Chinese Wushu, they have neglected the theoretical research of Chinese Wushu. Only by studying Chinese Wushu theory can we promote the innovation of Chinese Wushu, and then it can be loved by contemporary people. For example, in the theoretical study of Chinese Wushu, we should pay attention to the re-recognition of the Chinese Wushu concept, the type of Chinese Wushu and the contents contained therein. At the same time, Chinese Wushu also lacks research on modern sports systems. These studies are an important guarantee for the promotion of Chinese Wushu into international development. Therefore, people need to strengthen the study of Chinese Wushu theory. On the basis of research, people make an innovation of the content and form of Chinese Wushu, so that it can better meet the needs of contemporary people.

\section{B. Strengthening the Protection of Chinese Wushu}

Chinese Wushu is associated with national language customs, festivals, living habits, ethics, religious beliefs, codes of conduct, values, ways of thinking, ideology, and mentality [2]. The loss of the current Chinese Wushu connotation affects its further development. Therefore, in the course of Chinese Wushu protection in China, we must pay attention to the protection of its connotation. If you do not pay attention to the protection of Chinese Wushu, it will make Chinese Wushu confused with competitive martial arts, which will make Chinese Wushu completely disappear. Therefore, China should pay attention to the protection of Chinese Wushu, especially the protection of Chinese Wushu. First of all, it is necessary to integrate the connotation related to Chinese Wushu culture, clarify the connotation of Chinese Wushu, and incorporate Chinese Wushu culture into China's cultural protection strategy, and eliminate the loss of Chinese Wushu cultural connotation. Second, we must strengthen the protection of the Chinese Wushu heirs, they are the key to the inheritance and development of Chinese Wushu. Therefore, strengthening the protection of the Chinese Wushu heir is also the key to protecting Chinese Wushu. In the process of protecting them, it is necessary to play a synergistic role, abandon sectarianism, and encourage each sect to expand the disciples. The Chinese Wushu heirs can be provided with pension subsidy services to provide a strong guarantee for their lives, thus promoting the development of Chinese Wushu.

\section{Strengthening the Promotion of Chinese Wushu}

In the protection process of Chinese Wushu, it is necessary to strengthen the promotion activities of Chinese Wushu, awaken people's awareness of Chinese Wushu protection, and let people know the importance of Chinese Wushu to the country and its own development. In turn, Chinese Wushu is fundamentally protected. At the same time, it is necessary to increase the propaganda of the meaning and essence of Chinese Wushu, so that contemporary people can better understand the spirit of Chinese Wushu and enhance the interest of contemporary people in learning Chinese Wushu. In turn, it promotes the better learning of Chinese Wushu by contemporary people. In the promotion of Chinese Wushu, it is necessary to change the traditional paper propaganda mode. On the one hand, with the help of the news media, the people will re-recognize Chinese Wushu, especially some parents. This enhances students' enthusiasm for learning Chinese Wushu and promotes the inheritance of Chinese Wushu. On the other hand, Chinese Wushu heirs use the Internet platform to enhance the promotion of Chinese Wushu, create web pages in the Internet platform, and make Chinese Wushu training mode into video and send it to the Internet platform. In this way, people who like Chinese Wushu can obtain relevant Chinese Wushu videos through the Internet platform to meet the needs of contemporary Chinese Wushu, and thus promote the promotion of Chinese Wushu.

\section{Strengthening the Promotion of Chinese Wushu in Physical Education}

The inheritance of sports culture has its own unique way of inheritance, which is practiced through the inheritance of ideas, physical exercises, and skills. [3] The school is a place to cultivate talents, and Chinese Wushu is closely linked to the school's physical education curriculum. Therefore, in the protection of Chinese Wushu, it is necessary to play the role of the school and incorporate Chinese Wushu into physical education. It is necessary to strengthen the promotion of Chinese Wushu, popularize the importance of Chinese Wushu to student development, and let parents support students to learn Chinese Wushu, thus promoting the integration of Chinese Wushu and education. The school can be included in the physical education curriculum system by Chinese Wushu. This not only enriches the form of physical education, but also enables students to know, learn and pass on Chinese Wushu, thus promoting the overall development of Chinese Wushu.

\section{CONCLUSION}

Chinese Wushu is a unique traditional Chinese sports that focuses on both internal and external qualities. It takes the form of external physical exercise as the guide, and the inner self-cultivation as the guide, and the actual combat as the essence, demonstrating the patriotism and loyalty of Chinese Wushu, respect for teachers, justice and bravery, fitness, harmony with nature, and spiritual pursuit and values that focus on internal qualities. Chinese Wushu has experienced thousands of years of inheritance and development, forming the Chinese Wushu morality, an important Chinese Wushu morality and cultural outlook. Chinese Wushu combines with traditional Chinese philosophy, TCM health, religion, literature, etc. to form a unique Chinese Wushu culture. In the era of peace, the essential utility of martial arts combat martial arts has gradually weakened, but the Chinese national spirit of advocating powers has never ceased to exist, and will continue to accompany the pace of Chinese advancement until the realization of the Chinese nation's great rejuvenation of the Chinese dream. 


\section{REFERENCES}

[1] Li Quanshi, Li Minghua, Han Qiang. South of the Five Ridges Culture (Revised) [M]. Guangzhou: Guangdong People's Publishing House, 2010. (in Chinese)

[2] Wu Ming, Chen Yingchuan. On the value investigation and development strategy of national traditional sports culture resources [J]. Journal of Shandong Institute of Physical Education and Sports, 2006, 22(6): 46-49 (in Chinese)

[3] Jiang Xia. The tradition of sports culture in the new era is endless [N]. China Sports Daily, 2018-11-12 (007). (in Chinese) 